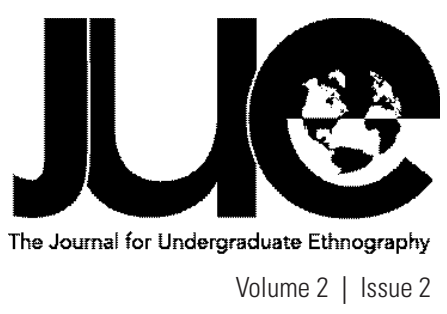

\title{
Gender Differences in the Use of Gay Clubs: A Place to Resist Gender Norms for Gay Men and a Place of Diffusion for Lesbian Women
}

Kimberly Eichenberger

Portland State University, Kimberly.Lynn714@gmail.com

\section{ABSTRACT}

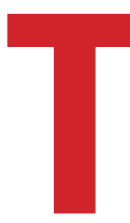

his article is based on an ethnographic study of the gay dance club subculture at Flames, a popular gay dance club in a Northwest city. I spent approximately 18 hours in the field making observations and interacting with subculturalists.

Utilizing the known researcher role and the participant observer role on different occasions, I conducted informal interviews using the guided conversation method. Through observing the behavior of gay men, expressed mainly through dance, I tried to understand the ways in which gay males perform gender. By engaging in feminine forms of dance to female pop music artists and openly expressing their sexuality, gay men in the dance club subculture resist hegemonic masculinity norms of the dominant culture. Gay dance clubs function as important spaces of acceptance for gay men and lesbian women. However, female heterosexual diffusion has helped push lesbian women to the periphery of the subculture, leaving them with little space of their own. This aspect of my study branches out from previous literature in the United States, which has mainly focused on gay men's experiences in gay clubs.

Keywords: Ethnography, Gender, Cultural diffusion, Gay dance clubs, Subculture 


\section{INTRODUCTION}

I first became interested in the gay dance club culture when I was introduced to the scene by two of my gay friends. On Halloween night 2011, we went to a gay dance club in the Northwest that also features Drag Queen shows. Having been to a few straight dance clubs, I was pleasantly surprised with the gay club. My experience with straight dance clubs has been less than desirable. I have found that gender roles are inflexible and females are reduced solely to sex objects. At the gay club, however, I felt comfortable and accepted. I could dance and have a good time with my friends without feeling pressured to conform to stereotypical behaviors associated with femininity. Gay and lesbian couples could openly display their sexuality without worrying about homophobic insults. Following my introduction into the scene, I decided that I would study the gay dance club subculture to better understand how gay men perform gender in this space and how they interact with lesbian subculturalists.

Gay men and women have not always had access to space specifically, and explicitly, designated for homosexual gettogethers and encounters. From the early 1900s to the 1960s, police arrested and prosecuted individuals who frequented gay bars in the United States. In 1965, Northwest Oregon bar owners began hiring attorneys because law enforcement was trying to shut down their establishments (Oregon Encyclopedia 2008). New York's Stonewall Riots in 1969 marked the first time in history that gay men and lesbians fought back violently against police discrimination (Peterson 2011). This sparked a new era of gay liberation throughout the country. Gay men and lesbians started organizing in Northwest Oregon in March of 1970, following the riots (Oregon Encyclopedia 2008).

Accompanying a newly emerging freedom to express one's sexuality was the invention of disco music by Black DJs. Disco was the perfect catalyst to all night dance parties. The upbeat, soulful records featuring female vocalists encouraged gay men to feminize their dance moves (Peterson 2011, 613). Disco culture provided a safe space for gay men to express their sexual desires for one another. Toward the end of the 1970s, however, disco began to diffuse into mainstream culture, losing its value among marginalized populations. Disco was popular among heterosexuals until 1979 when it was criticized for its homosexual connotations (Peterson 2011). The backlash against disco and its link to homosexual deviancy prompted more than 50,000 individuals to gather at a Chicago baseball stadium to participate in the detonation of their disco records while chanting “disco sucks!" (Peterson 2011, 614; Blazak 2012). 
After disco was laid to rest by heterosexual conservatives in 1979, and following the election of Ronald Reagan in 1980, there was a cultural shift toward masculine ideals. With HIV and AIDS coming to the forefront in the 1980s, stigma of the gay male population greatly increased. The social stigma contributed to a system of hegemonic masculinity and gender norms still present in our society today. Effeminate gay men were specifically stigmatized and thought to be HIV positive. Muscular, straight-looking gay men were conceptualized as being HIV negative. (Peterson 2011).

The impact of this stigma on the gay male population changed the way gay men presented themselves. In response to homophobia, many gay men began to masculinize their dance moves and act in line with hegemonic masculinity norms of the dominant culture. Accompanying these ideals was a switch from 1970s disco dance clubs to gay male circuit clubs featuring electronica music, which were popular throughout the 1980s and 1990s (Peterson 2011, 617). The gay circuit dancer is generally muscular and has rigid, pulsing dance moves. Strict self-regulated gender codes coupled with electronica music prevent gay circuit dancers from performing feminized compositions, including sexualized dancing with a partner (Peterson 2011, 618). The gay dance club Flames, where I conducted most of my research, was established in the early 1980s, during the conservative era. It opened as a gay country western bar where mustached men wore Wranglers jeans and cowboy boots while line-dancing to Billy Ray Cyrus. Although it provided a different scene than the gay circuit dance clubs in the "Pink Triangle" section (see Appendix A) of the city, it was a far cry from the once feminized disco culture of the early 1970s (Oregon Encyclopedia, 2008). In fact, the club kept its country theme throughout the 1990s, appealing to the culturally closeted gay population.

In the early 2000s, after HIV and AIDS had reached heterosexual populations, fewer people directly associated the virus with gay men. During this time, there was a gradual cultural shift in attitudes toward gay men and lesbian women. Gay and lesbian populations were granted more rights, such as protection against employment discrimination. Hate-crime laws were enacted to provide more punitive sanctions for individuals who committed crimes against others based on their sexual orientation (Oregon Encyclopedia 2008). Lesbians and gay men were more positively presented in the media than they had been prior to the 2000s (Peterson 2011).
Also during the early 2000s was the explosion of pop culture. Many dance club DJs traded electronica music for top 40 hits. Top 40 hits, featuring many female vocalists, seemed to complement the cultural decrease in homophobia and allowed for more feminized dance in gay clubs (Peterson 2011). By 2003, Flames had also changed to accommodate the new pop music culture. The hay bales and wagon wheels were traded in for a dance floor surrounded by mirrors and a 22,000 watt sound system. It currently operates as one of the city's most popular LGBTQ dance clubs (see Appendix A).

My original theory was informed by the notion that gay men in the dance club subculture "do gender" differently than do heterosexual males in the dominant culture. To understand this subculture further, I organized my study around four specific elements: gender roles, lifestyle, settlements, and social world (Lofland and Lofland 1995). By focusing on gender roles, I could understand how gay males in the dance club subculture perform gender. Lifestyle analysis includes the music, clothes, and dance associated with the subculture, along with the values and norms accompanying them (Blazak 2012). Studying the settlements of the gay dance club culture allowed me to understand what was important about gay dance club space and what attracted individuals to it. I also wanted to find out more about the social world of gay dance clubbers, including the ways in which they interact with lesbian dance clubbers and heterosexuals who also utilize gay dance clubs.

\section{LITERATURE REVIEW}

R.W. Connell (1992) studied how gay men either embraced or negated hegemonic masculinity. The concept of hegemony, originated by Gramsci (1971), refers to the exertion of power by subtle means (Williams 2011, 89-91). Rather than dominating someone by force, hegemonic power is achieved through consensus. Consensus is developed by our cultural institutions; schools, family, media, church, and others. The dominant culture exerts power over individuals by getting them to conform, without questioning the social order. Hegemonic masculinity can be understood as the way in which mainstream culture defines masculinity and gets individuals to adhere to this definition, not by coercion, but rather through their own consent. Individuals come to believe that things are the way they are and accept gender norms as the natural order (Williams 2011). 
Connell's (1992) article mainly focuses on masculinity and gender roles among gay men. Connell states that masculinity in the dominant culture is marked by homophobia and a hostile attitude toward homosexuals in general. Homophobia is a tool that heterosexual males use to "police" each other's gender roles (Connell 1992; Peterson 2011). Lauraine LeBlanc (1999) conceptualizes masculinity in the dominant culture as the repudiation of femininity, with masculinity seen as superior to femininity (LeBlanc 1999). Thus, according to hegemonic masculinity norms, homosexual men who possess feminine attributes are seen as less masculine and therefore inferior.

Using the life-history method for his study, Connell sought to understand the personal trajectories of gay men in Sydney, Australia and how they negotiated masculinity. Connell found that in childhood, there was little evidence of gender nonconformity. Most of the men were socialized in "typical" masculine ways; they played sports, such as rugby and football, and most of them had previous sexual relationships with women (Connell 1992). However, many of the men began to have sexual attractions to other men during adolescence, which separated them from heterosexual male peers.

Around the age of 20 , some of the men came to the conclusion that they were gay. In the process of "coming out," one of the men in Connell's study went to a gay dance club and another resisted hegemonic masculinity by wearing hipster jeans, painting his nails, and knitting. A few of the men embraced their gay identity as a way to freely express their sexuality. Connell concluded that overall, most of the men in his study were ambivalent to hegemonic masculinity and did not challenge the gender order. However, he acknowledged that by engaging in nonconformist sexual behavior, there is a possibility for social change in the way that gender is structured (Connell 1992).

Grant Tyler Peterson (2011) conducted a study on gay men's dance styles at the club TigerHeat in Los Angeles, California. I chose this article because of his focus on gay male dance choreographies in gay clubs. In fact, this was the only article I found that specifically explored the feminization of gay men's dance compositions. Music at TigerHeat features female vocalists, top 40 hits, and dance remixes. Performing as a go-go dancer at TigerHeat allowed Peterson to closely observe dance choreographies and gender expressions of gay male dance clubbers. He conducted fieldwork in 2002; a year after TigerHeat first opened its doors (Peterson 2011).

Peterson found that by dancing to pop music that would generally appeal to heterosexual teeny-boppers, male dance clubbers at TigerHeat take heteronormative associations and change them into gay expressions (Peterson 2011, 621). Thus, instead of seeing a teen girl dancing to Britney Spears and Christina Aguilera, at TigerHeat, one would find gay men and Drag Queens engaged in feminine forms of dance with their gay partners. At the beginning of his study, Peterson mocked the music. However, as a gay go-go dancer, Peterson gradually found himself enjoying the pop rhythms and reclaiming the music as an important form of self-expression for gay men (Peterson 2011, 621).

Unlike the electronica music of the circuit clubs, pop music allows dancers to move more fluidly and engage with other dancers. Peterson found that gay men at TigerHeat performed sexual dance choreographies to pop song lyrics with other male dancers. He concluded that as society gradually shifts away from homophobia, gay men's dance choreographies become more feminized (Peterson 2011, 622). Thus, men are not restricted to perform hegemonic masculinity roles on the dance floor. Instead, they are able to express sexuality through dance in a more exposed and less stereotypically masculine way (Peterson 2011).

In order to understand more about the importance of gay dance clubs, I reviewed an article by Martin Holt and Christine Griffin (2003) that focused on identity and authenticity in the gay scene. Holt and Griffin's study was conducted in Birmingham, United Kingdom between 1998 and 2002. They interviewed 61 young adults between the ages of 17-34 and included heterosexual men and women in their sample. The purpose of the study was to understand how leisure spaces, such as bars and clubs, gave lesbians and gay men the opportunity to express their identities. They also wanted to find out how heterosexuals used these spaces (Holt and Griffin 2003).

Public space is assumed to be heterosexual space, unless otherwise specified. In these spaces, individuals are expected to conform to heterosexual norms. The result is that LGBTQ individuals often feel "out of place" in everyday life and there may be consequences if she or he deviates from heterosexual norms (Holt and Griffin 2003, 409). Thus, there is an inherent importance in creating one's own space. Lesbians and gay men have established communities and venues, such as bars and dance clubs, where they can safely be "out" (Holt and Griffin 2003; Casey 2004). In the United Kingdom, these areas are sometimes referred to as "gay villages" (Casey 2004, 447) and in the United States, as well as London, they are occasionally referred to as "Pink Triangle Districts" (Oregon Encyclopedia 2008; Casey 2004). 


\section{“ LESBIANS AND GAY MEN HAVE ESTABLISHED COMMUNITIES AND VENUES, SUCH AS BARS AND DANCE CLUBS, WHERE THEY CAN SAFELY BE'OUT'." (HOLT AND GRIFFIN 2003; CASEY 2004)}

Holt and Griffin (2003) point out that gay bars and clubs are commonly the only public places in which lesbians and gay men can openly express their sexuality (Holt and Griffin 2003, 409). Their findings suggest that gay bars and dance clubs are perceived as places of acceptance and are utilized as an escape from the heteronormative dominant culture. However, gay bars and dance clubs are not without their own sets of codes, although these codes may differ from the ones found in mainstream culture. Two of the lesbian women in the study said that wearing 'femme' clothing in certain clubs elicited judgmental stares from other lesbian patrons (Holt and Griffin 2003, 412). Similarly, some of the gay men in the study stated that failing to dress up to go out to the clubs resulted in feeling like they did not belong (Holt and Griffin 2003). In other words, these are spaces of acceptance for gay men and lesbians as long as they follow gay and lesbian cultural norms.

Holt and Griffin (2003) found that many of their heterosexual participants also enjoyed 'gay space' and that an increasing number of heterosexual women were frequenting gay clubs. The researchers termed this concept "heterosexual tourism" (Holt and Griffin 2003, 414), in which heterosexual women and men go to view the "exotic other" (Casey 2004, 448). Mark Casey's (2004) study focused on the ways in which queer space has diffused into mainstream culture to include a growing number of heterosexual women who frequent gay bars and clubs. Casey conducted interviews in London between 2001 and 2002 with 12 lesbians and 11 gay men (Casey 2004).

Many of the lesbians in his study stated that gay clubs have become trendy places for heterosexual women to hang out with their gay male companions (Casey 2004, 450). Heterosexual women may seek relief from the objectifying heterosexual "male gaze" that is constantly present in straight bars and dance clubs (Casey 2004, 448; Holt and Griffin, 2003, 414). Gay clubs allow heterosexual women to escape rigid femininity roles. In fact, the desire to avoid the objectifying "male gaze" for heterosexual females generally outweighs any anxiety about a potential lesbian gaze (Holt and Griffin 2003, 414).

Holt and Griffin (2003) and Casey (2004) discuss the innate problems with the diffusion of gay space. The researchers point out that it may not be as problematic for gay men, as they often are the ones who bring heterosexual female companions into the bars and dance clubs (Holt and Griffin 2003; Casey 2004). However, it can be quite problematic for lesbians, as they become excluded from a space that was once theirs (Holt and Griffin 2003). Lesbian women may feel as though they are no longer able to express their sexuality in a way that will not be judged. Some of the lesbians in Casey's study discussed their discomfort with the presence of heterosexual women in gay clubs and bars, stating that they were afraid straight women would think they were flirting with them (Casey 2004, 454).

Very few "lesbian only" clubs exist in the United Kingdom, London, or in the United States (Casey 2004; Holt and Griffin 2003). In my search of gay and lesbian night clubs in Northwest Oregon, I found that there are no clubs specifically for lesbians. There was a lesbian dance club years ago that shut down and re-opened recently under a different name, marketing itself as a "mixed" (LGBTQ and straight-friendly) club. Male domination of subcultural space is not a new concept. For example, LeBlanc discusses the male numerical domination in the punk subculture (LeBlanc 1999, 105-106). Female subculturalists are often pushed out to the periphery of male dominated subcultures. They are allowed to participate, but only if they adhere to norms and values defined by males (Blazak 2012).

Lesbian women in Casey's (2004) study explained that gay dance clubs and bars are set up as male spaces. Everything from the music to the bouncers is catered toward gay men's preferences (Casey 2004, 455). As heterosexual women began frequenting the dance clubs and bars, many lesbian women were pushed out of the subculture even further. Some of the lesbian women felt that they had been completely excluded from these establishments (Casey 2004; Holt and Griffin 2003). Casey suggests that because gay men and heterosexual women both sexually desire men, it creates a commonality and shared experience that separates them from lesbian women (Casey 2004, 453).

Although there are many articles written on studies that have been conducted with gay and lesbian populations, there are few that focus specifically on the gay dance club subculture. Peterson's (2011) study was the only article I found that focused on gay male dance choreographies. Much of the research on gay and lesbian space, as well as the diffusion of gay clubs into mainstream heterosexual culture has been conducted in Birmingham, United Kingdom (Holt and Griffin 2003) or in London, UK (Casey 2004). My goal is to fill the gap in the research, by focusing on gender roles in the gay dance club culture and the importance of gay dance clubs to subcultural participants. My study also reveals the effects of heterosexual diffusion on lesbian dance clubbers in the Northwest. 


\section{METHODS}

I chose to conduct my research at Flames because of its popularity among LGBTQ individuals. Prior to beginning my research, I frequented a number of gay dance clubs in the area. Some of the other clubs I visited had much fewer individuals on the dance floor. Many patrons were sitting at the bar or talking amongst themselves. At Flames, however, there were a much larger number of individuals in the establishment and on the dance floor. This club had also been recommended to me by a lesbian friend as a place where the younger LGBTQ crowd hangs out.

My relationship to the site was somewhere between a blank slate and a convert. Although I had been in four LGBTQ clubs prior to this one, I had no experience in this particular club. Being a blank slate allowed me to carefully observe detail, without overlooking aspects I may have taken for granted if I had visited the club prior to my research. However, having been in gay clubs before helped me "fit in."

As a 26-year-old white female, my ascriptive characteristics were similar to those of individuals in the gay dance clubs. I was within the median age range; some individuals were younger than I and others were older. Gay dance club culture is a predominantly white subculture, as pointed out by multiple researchers (Holt and Griffin 2003; Casey 2004). As a female, I was outnumbered by men at the dance clubs. Previous research has also noted that this is a male-dominated subculture (Holt and Griffin 2003; Casey 2004; Peterson 2011). Being bisexual helped me interact with gay men as well as lesbian women because I could relate to both. While conducting research at this particular club, there were not any moments where I felt out of place.

The data site I chose was easy to get into, but was also secure. Flames does not charge a cover fee 363 days out of the year, which may be one of the reasons it is popular with the younger crowd. Muscular, bald headed bouncers stand outside the front door and check IDs and purses before letting people into the club. They also make sure that no one attempts to take their alcoholic beverage outside of the club. Due to the fact that the restrooms are coed, a bouncer frequently monitors both bathrooms to make sure no one is sharing a stall, as this would raise safety concerns for some patrons. At no time in my fieldwork did I witness any violence or bar fights, nor did I feel unsafe at Flames.
My contacts for this research were two gay male friends who are also part of the gay dance club subculture. They helped introduce me to the culture, went out with me on many nights, and were subsequently part of my sample. With these contacts, I was able to develop a rich understanding of gay masculinity and the importance of gay dance clubs for subculturalists. Entering the scene with these contacts also helped me "fit in," as some of the other gay men at the club also brought their female friends.

I used multiple research roles throughout my fieldwork. Although I was a known researcher to my contacts and one of my bisexual female friends, I remained a participant observer or a complete observer to the rest of my participants. Utilizing the known researcher role with my contacts, I was able to ask more questions using the guided conversation method. The guided conversation method is an informal interview, which involves asking open-ended questions and allowing the participant to respond without restrictions. My contacts did not know why I was conducting research, but because my role as a researcher was known, it may have affected my internal validity. On evenings that I focused on style, dance choreographies, and music, I used a complete observer research role. I sometimes sat at the tables to the side of the dance floor at or next to the bar in order to observe participants from a distance.

The final research role that I used on some evenings was the participant observer. I danced, drank, and interacted with participants in order to make close observations. This also allowed me the opportunity of self-reflexivity, blurring the line between myself and my participants (Tunnell 1998, 214215). By understanding my subjective enjoyment produced by participating in this subculture, I could better understand how subculturalists experienced a sense of enjoyment, as well. Through participant observation, I was able to utilize the guided conversation method to ask lesbian participants about their views on the subculture and how they felt about heterosexual diffusion (see Image A).

I entered the field initially with one of my contacts. This gave me time to make some observations about the club in general and ask him questions about his subcultural participation. On nights that I entered the club without my contacts, I brought other friends. In this setting, it was important to enter the field with at least one other person. Had I frequented the 
dance club by myself, I most certainly would have stuck out, and participants may have altered their behavior, suspecting I was there for other reasons than dancing and drinking. This would have negatively affected my internal validity.

In order to accurately log data, I wrote dialogue and other observations down immediately. I kept blank paper and a pen in my purse and excused myself to the restroom throughout the evening in order to transcribe dialogue (Blazak 2012). While making other observations regarding music, style, and dance choreographies, I texted myself the information. In order to keep guided conversations natural, I wrote down questions prior to entering the field, but asked them nonchalantly and only when appropriate. I kept a field notes journal in my car so I could easily transfer notes and dialogue after leaving the dance club. In order to maintain confidentiality, I used pseudonyms for my participants and my primary and secondary data sites (Blazak 2012).

The sampling technique I employed was convenience sampling. I included subjects in my sample who were close at hand and readily available. This method allowed me to gather data from subjects nearby at my convenience. Convenience sampling is less expensive than other research methods and it is less time consuming. However, it is not without limitations. There are inherent problems with generalizability and replication. Convenience sampling is also subject to researcher bias (Babbie 2005). To minimize some of these limitations, I attempted to include subjects who I felt represented the subculture overall. For example, after multiple nights conducting research, I began to see some of the same faces. I made sure to include these individuals in my sample, as they seemed to be "regulars" in the gay dance club subculture and more representative than someone who only participates once a month.

The characteristics which informed how I made sense of my observations, and for which I coded for, involved conceptualizing data through elements such as: gender roles, lifestyle, settlements, and social world. I grouped themes of data based on these elements. At the end of my field research, I went through my field journal and color-coded each entry by its corresponding element of focus. I also included an "other" category in order to be exhaustive. After coding for these components, themes emerged from my research that helped form my grounded theories (Lofland and Lofland 1995; Blazak 2012).

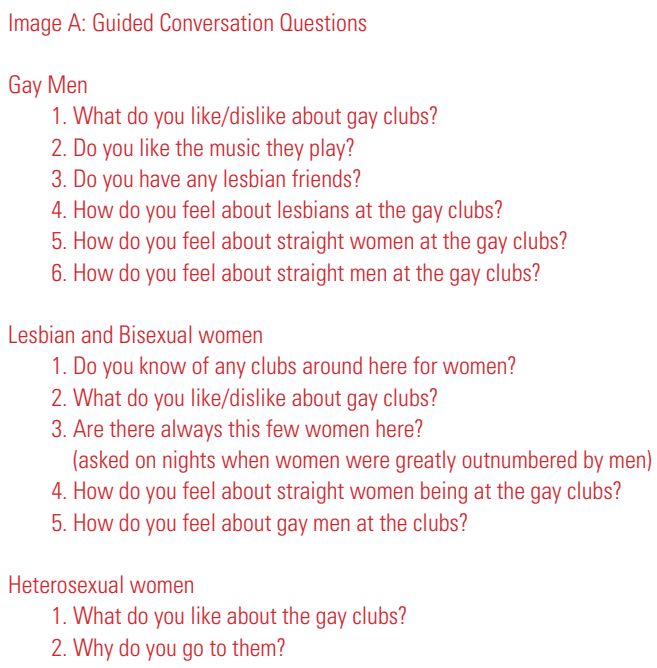




\section{FINDINGS}

My sample size included 24 individuals (approximately 14 gay males, 6 lesbian females, 2 bisexual females, and 2 heterosexual females). Their ages ranged from approximately 21 to 35 years old. The majority of my sample was middle class and 79 percent white, 13 percent black, and 8 percent Hispanic. This reflected the overall demographics of the subculture. I spent six Friday and/or Saturday nights at my primary data site, for a total of approximately 18 hours. In addition to frequenting the dance club, I also spent time at secondary data sites, such as gay bars, other gay dance clubs, and the home of my two contacts.

Gender Roles and Lifestyle: The beginning of my study was focused on observing gay men and the ways in which they perform gender. On my first night in the field, I entered with one of my contacts, a white 27 -year-old gay male wearing a bright yellow zip-down sweater, a fitted dark gray t-shirt with dark denim pants and black dress shoes. We found a place to stand next to the bathrooms, just behind the dance floor. This space was ideal for observing subculturalists, as it was located in between both bars and it gave me a direct view of the dance floor. While sipping Heineken with my contact, we engaged in a guided conversation (see Image A).

Gay men in the dance club subculture perform gender differently than do heterosexual men in the dominant culture. Gay men in the dance club subculture were actively engaged in conversation with other gay men and some straight women when they were not dancing. Their body language was generally open; arms uncrossed, feet apart. At times, many of the men became theatrical, with animated movements and hand gestures. Some of the men I observed arched their backs, accentuating their backside with their hand on their hip while talking to other men.

I also observed the ways in which gay men interacted with each other. Many gave flirtatious looks out of the corner of their eyes, gazing at their partner or another patron at the dance club. Gay men who were not interacting with the dance floor often stood close together, sometimes caressing each other sensually or touching each other's chests with a gentle playfulness (see Image C). Gay men who were there with a partner engaged in public displays of affection, including deep kissing. Gender performance was much more fluid and less macho among gay men in the dance club culture. 


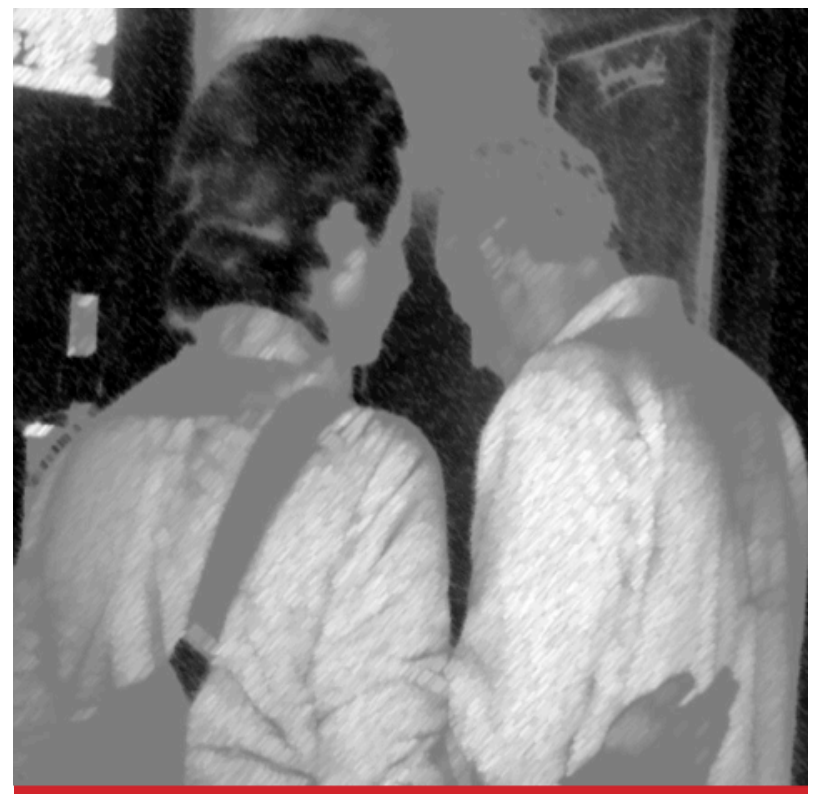

Image B: Gay partners in the club

"Relationships are more equal. We can't do the same thing as straight couples-we don't have anything to go off of," stated Eddie, a subcultural participant. This avowal implies that gay men are not confined to strict gender role performance in relationships the same way that heterosexual couples are. Gender roles for gay men in relationships tend to be more egalitarian and allow for the emergence of "feminine" traits. One similarity, between straight masculinity in the dominant culture and gay men in the dance club culture that I observed, is that both are often outgoing and competitive. Gay men in the dance club culture tend to be forward about what they want. For example, as I was sitting at a table conversing with Eddie, a young blonde haired man in a tight V-neck t-shirt walked by, tapped him on the chest, and said, "You're cute!"

Gay men in the dance club culture are also style innovators. Many demonstrate Hebdige's concept of bricologe (Blazak 2012), which is the repositioning of raw materials from the environment in order to change their values. On numerous occasions, I observed gay men with either low-cut or self-cut $\mathrm{V}$-neck t-shirts to show off what I call pec-cleavage, which is the space between a man's pectoral muscles. One of the gay men I observed fashioned a white bandana into a short necktie and another cut vertical slashes into the front of his black tshirt. One of the men in my sample wore tan colored overalls with one strap undone, no shirt underneath, and a blue bandana hanging out of his back pocket. A few of the men in my sample cuffed the bottom of their pants and paired them with black dress shoes.

Most of the clothing in the gay dance club culture is wellfitted, including stressed jeans, muscle t-shirts, polo shirts, and bright colored button-downs. Eddie stated, "Everything is tight to show off assets. It's the same reason women wear tight clothes." Gay men in the dance club culture wear skintight clothes to show off their bodies to other men in order to attract a potential mate or simply to get attention. All of the men in my sample had short hair; some wore it spiked, others had faux hawks, and some wore their hair with bangs pushed off to the side of their foreheads. None of the gay men I observed had visible tattoos and only one had gauged earrings. Some of the white men in my sample appeared to have a tan and one subject had a large cream-colored purse over his shoulder and wore eyeliner.

Trying out new styles and experimenting with different looks seemed to be popular among my sample. Some of the styles were criticized and others were commended. Jayson, a 30 year old Black gay male, stated, "They need to let the faux hawk go," referring to this hairstyle being outdated. Commenting about the clothing style of gay club culture in general, Jayson stated, "People put the weirdest clothes together just to try it out and some people will catch on to it." This helps demonstrate the importance of style in gay club culture and the innovation process.

Flames dance club played mostly top 40 hits from female pop artists. Some of these artists included Lady Gaga, Britney Spears, Nicki Minaj, and Katy Perry. The gay male DJ who mixes these hits in a booth above the dance floor played a male pop artist remix every once in a while. I spent an hour focusing on the music during which I counted one male artist; Flo Rida's (2012) hit "Wild One," that also features Sia (a female pop artist).

Music at the club was upbeat and remixed for dancing. Many of the lyrics were sexualized. For example, lyrics from one of the Britney Spears songs that played were: "If I said I 
want your body now, would you hold it against me?" Songs were also heteronormative, with female artists singing to their male lovers. Gay men in the dance club subculture align themselves with the music, reverse the heteronormative connotation, and direct their sexuality toward their male lovers. Although many gay men enjoy dancing to this music, some wish the club incorporated a few slower songs to give them a chance to try other forms of dancing. "I wish there was more of a mixture. Gay guys don't get to slow dance anymore. I would have some slow jams playing if I had a club," Jayson explained.

With the music fast and the lyrics sexual, gay men in the dance club subculture perform dance choreographies often involving other men. Dance choreographies tend to be fluid and feminized with sensual hip movements in a figure-eight pattern. Dancers focus on the beat of the music and adjust their dance choreographies to fit the rhythm. Two of the men in my sample that I observed acted out their sexual fantasies on the dance floor. A blonde-haired man wearing tight jeans and a muscle shirt pushed his dance partner up against the long row of mirrors that line the dance floor and kissed him deeply. He then slid down to his partner's knees and came back up while looking into his partner's eyes, similar to the way a female erotic dancer would entice her male client.

I asked one of my participants about the dance choreographies of gay men and he responded: "I'm not sure why movement becomes more feminized. It may be due to gay socializa- tion or it may be natural." Gay men, upon entering the dance club subculture, might observe others dancing and adopt a similar style; or it may be a natural performance in which the dance club provides the outlet.

Gay men's dance choreographies are quite different than most heterosexual men's dance choreographies in straight nightclubs. To make a general comparison between Flames and a straight dance club, a gay participant and I ventured a few blocks down from Flames to a straight dance club I will call Vanity. Eddie commented on straight men's dancing at the club, stating, "Straight men look like they're being electrocuted." Straight men's dance follows the rules of hegemonic masculinity. It tends to be rigid, rough, and lacks the fluidity and creativity that gay men's dance choreographies generally contain.

Music at Vanity was male dominated, with hip hop remixes and derogatory lyrics toward women. Wearing casual attire-a knee length skirt and a black, long sleeve button-down shirt, I was immensely under-dressed for the straight club. Most of the women there wore bright colored strapless dresses that ended just below their buttocks. They elongated their tan legs with four inch heels and danced with each other on top of picnic tables to Sir Mix-A-Lot's "Baby Got Back" while men in jeans and t-shirts watched them from below. Eddie and I wanted to leave the club as quickly as we had entered. Straight women and men at Vanity performed gender much differently than did gay men and lesbians at Flames.

\section{“ EVERYTHING IS TIGHT TO SHOW OFF ASSETS. IT'S THE SAME REASON WOMEN WEAR TIGHT CLOTHES." -EDDIE}

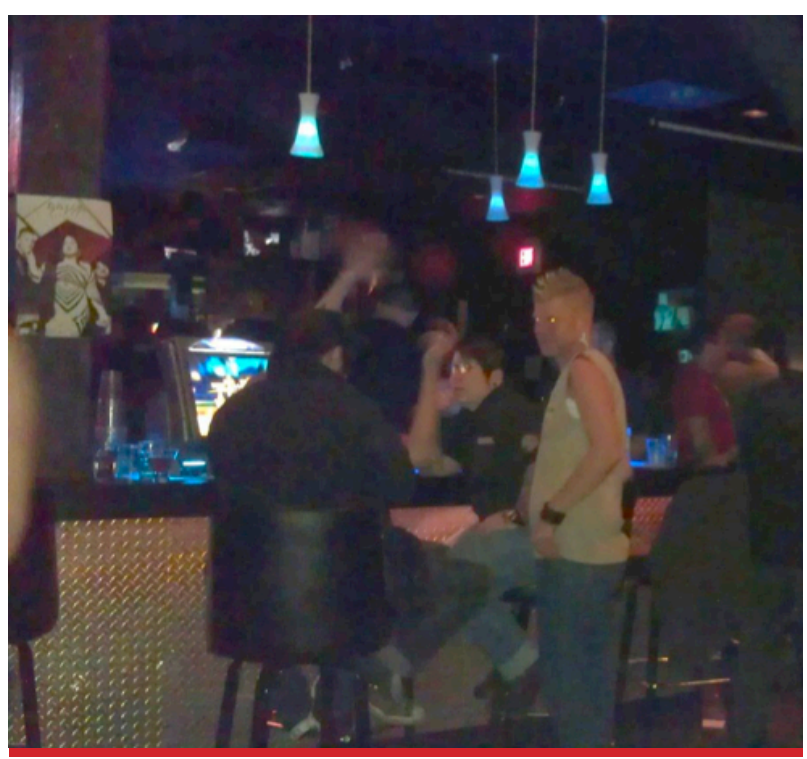

Image C: A gay subculturalist with a faux hawk 
Settlements: Before entering Flames, one can tell it is primarily an LGBTQ dance club because of the rainbow flag hanging high outside the front doors. Along the sidewalk out front is a table with a cream colored awning designated for dance clubbers who smoke cigarettes and desire to escape the rain while doing so. Large, tattooed male bouncers check identification at the front door. Directly inside the club is a tall wooden rack with cubbyholes where patrons can set their drinks before going outside. Two black circular tables big enough for groups of five each are in the front next to big bay windows. Upon entering the club, the main bar has anywhere from three to five shirtless male bartenders pouring stiff cocktails and serving beer in glass bottles. Gay dance clubbers either sit at bar stools or congregate around the counter waiting for drinks or socializing with friends (see Image C).

To the right side of the bar are long leather booth-style seats against the wall paired with tall tables and chairs. Behind the main bar is the dance floor, which is full most Friday and Saturday nights between 11 p.m. and 2 a.m. On the side of the dance floor is a long area of black lights with a ledge where clubbers can set down their drinks. The coed restrooms are next to this area beside the second bar in the back of the club. The women's restroom has a large sign hanging on the entrance wall stating that this space is for "women....and men who wish to sit." The sign on the men's bathroom indicates that this space is for "men... and women who wish to stand." After making observations on multiple nights regarding the general traffic in and out of these restrooms, I realized that vastly more men use the women's restroom than women use the men's restroom.

The bar in the back of the club by the dance floor is smaller than the main bar in the front. It has two television monitors, one of which allows clubbers to send text messages to a certain phone number which will then appear on the screen for everyone to see. At this smaller bar, there are usually only two bartenders serving drinks. Also, to the left of the bar, there is a small area with two tables and chairs. The dance club is attached to a lounge where individuals can sit at cushioned bar stools and metal tables and order drinks and food throughout the night.

Loud pop music blasts through 22,000 watt speakers as the male DJ in a booth above the dance floor remixes top 40 hits by predominantly female vocalists. On the dance floor, it is nearly impossible to hear someone unless she or he is shouting.
To the sides of the dance floor and by the front of the club, it is a little easier to hear one another, although the music is still blaring in these locations. Lights are dim throughout the main club and on the dance floor, but are brighter in the lounge/restaurant area. Low-hanging neon lights give a colorful ambiance to each of the bars.

Gay dance clubs are important for gay men and lesbian women for many reasons; one being that public space is still seen as heterosexual space. Although gay men and lesbians are granted more rights now than in the past (Oregon Encyclopedia, 2008), mainstream society is far from accepting gay couples displaying their love for one another in public settings. "It's difficult to go out in public and hold hands the way that straight couples do. People look at you weird." One of my participants told me about a time when he and his boyfriend went to take outdoor photos as a couple. As they were posing for a photo, people drove by honking and shouting at them out of their car windows. He also added with a sigh, "Sometimes, we just don't hold hands in public because we don't want to deal with the scrutiny." Straight individuals take these things for granted; they can hold hands and kiss in public without being judged and verbally attacked.

Gay dance clubs provide a safe space for gay men to express their sexuality. At these places, there is a general feeling of acceptance and authenticity. Gay men can be themselves, embracing their true identities without the fear of judgment. It is also a space where gay men can meet and/or "hook up" with other gay men. Jayson states, "It's our last frontier for meeting people-besides online." Eddie also talked about meeting people at gay clubs versus meeting people in public settings: "This is the only place where people know for sure [that someone is gay]. You see someone at Barnes and Noble and have to guess." Gay men can "hit on" men at gay dance clubs and know that they are gay. In public settings, it can often be a guessing game, in which a straight man may get angry if approached by a gay man.

One of my participants discussed the changes he has noticed recently with the Northwest city's gay dance clubs. He states, "[the dance clubs] here have become cliquey. People go with groups of friends. It's like that in New York too. But at the gay bars in Austin, [Texas] and Louisiana people are more open to talking even if they're strangers." I asked him why he thought this was occurring and he replied, "There's not as much need for 


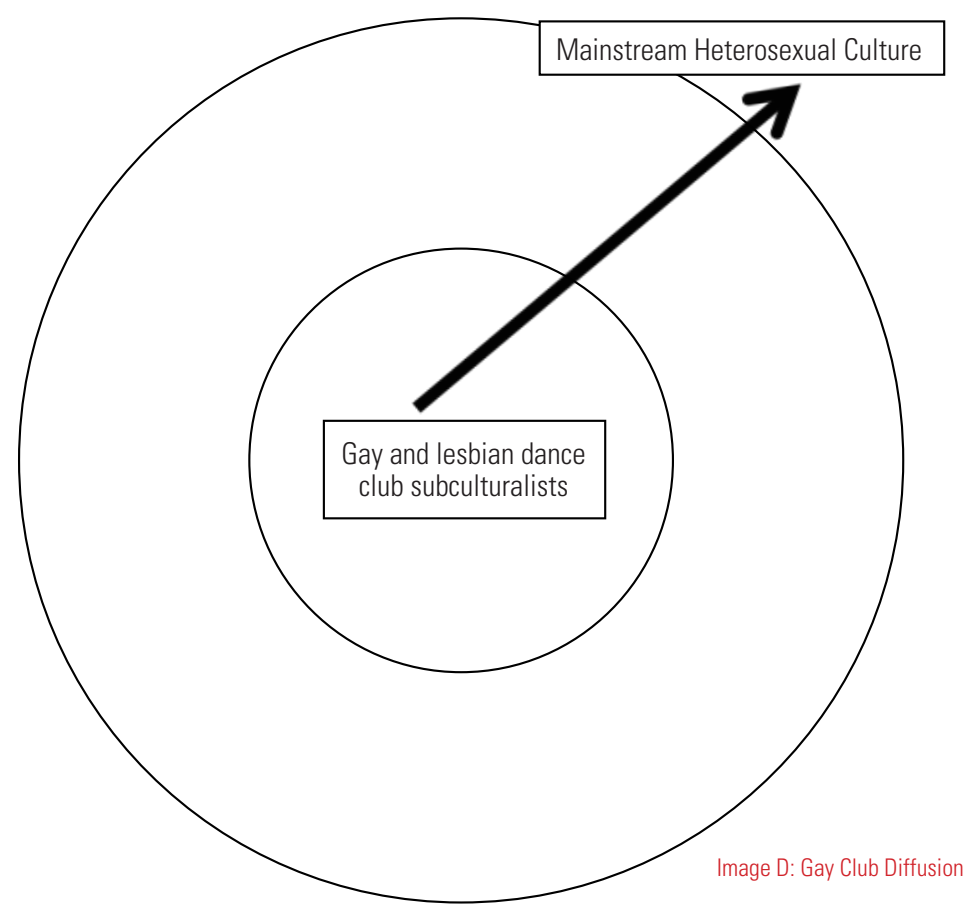

it in [this city]. In the South it's necessary to have a 'gayborhood.' I've seen couples walking around here. Here it's okay to hit on someone outside [the dance club] because they aren't going to feel as awkward." He suggests that residents of liberal cities are more accepting of gay couples than are residents of conservative Southern states. Gay clubbers in Southern states may seek refuge from mainstream heterosexual culture by utilizing the gay clubs as a way to meet others. Although the Northwest city where I conducted research is more progressive than some other cities in the United States, there is still a need for gay space, as gay and lesbian couples still are not afforded the same rights as heterosexual couples.

Social World: I wanted to better understand lesbian participation in gay dance clubs and how gay male subculturalists interact with them. Throughout my research, however, I noticed there was not much interaction going on. The first night I walked into the field, I wondered, where are the lesbians? There was an undeniable male numerical dominance and this was a finding I noted in my field journal on multiple occasions. Gay men vastly outnumbered lesbian women on the dance floor and in the club. In fact, there was only one night out of six that I observed lesbian women outnumbering gay men on the dance floor. It was on a Saturday night around 10 p.m. and the gay men were crowded around the bar preparing to make their dance floor debut. I mentioned my observation to one of my gay male participants and he replied, "I think most lesbians don't dance. They probably like bars better." I asked two of my gay male participants if they were friends with any lesbians and they both responded "no." One of them expanded on his answer by stating, "They're cool, but they scare me a little." "Why?" I questioned. "...Because they are abrasive. I've never had a lesbian friend before."

The more time I spent in the field, the more I noticed the ways in which lesbian women were subtly excluded from the gay dance club culture. Every shirtless bartender and bar back I encountered was male. Conducting an informal analysis online, I counted the number of days per week that Flames catered to gay men and lesbian women. Gay men were given eight time slots during the week in which the club was designated as their space. This included peak nights, such as Fridays and Saturdays from 9 p.m. to 2 a.m. Lesbian females were limited to one night a week in which Flames catered to their needs. This was an offpeak night (Tuesdays) from 9 p.m. to 2 a.m. I also conducted an informal analysis online of employees at this club and found that there were 12 male bartenders and bar backs and only one female bartender. There was one other female employee, working as coat check. This so-called "mixed" club was male dominated numerically, even among its employees.

I also observed a large number of straight women who frequented the dance club with their gay male companions. Around 11 p.m. most Friday and Saturday nights, the dance floor would fill up with gay men and their male or heterosexual female dance partners. One of the gay men I included in my sample looked like he had recently turned 21 and was out to have fun with a group of straight female friends. They danced together in a loose circle free from any sexual tension, while he glanced at men dancing nearby. Most of the lesbian women were on the periphery of the club-either standing near the back 
by the restrooms or sitting at tables by the front door. The gay men in my sample did not seem to be bothered by the amount of straight women in the club, as many of them brought their straight female friends "for support," as one of them stated.

A Latina lesbian female I met named Yvette with shoulder length wavy brown hair said that she liked the club because "there are a lot of people to talk to." Yvette came from a small rural town in Washington and had only been living in the Northwest city for a few months. Another lesbian I talked with who grew up in the area had different sentiments. Lisa wore a black muscle tank top with ripped jeans and had short brown hair styled into a faux hawk. Although she had two friends at the club black lesbian female and a trendy gay male), she came by herself and was looking to meet other lesbian women since she had broken up with her female fiancé a couple of months prior.

I approached Lisa with one of my female friends and asked if there were any clubs around for females. She responded: "Guys are everywhere. You're not going to find a club with just [lesbian] women." After stepping outside to make more observations, I ran into Lisa again and asked her for a cigarette to re-initiate conversation. She decided to accompany us to a more low-key bar, which was when I used guided conversation to find out her perspective on the gay dance clubs (see Image A).

In response to my question regarding how she felt about straight women at the club, she stated: "There are lots of heels and blonde hair tonight. It kinda sucks because we [lesbian women] already don't have a space for just us and they're taking over this too when there are lots of straight clubs they could go to." I asked why so many straight women were going to gay clubs and she said, "It's like they're finding out that dancing at gay clubs is a lot better than dancing with douche bags [at straight clubs]." As we walked by multiple straight clubs on our way to the low-key gay bar, I could visually see, based upon the way males were interacting with females inside these clubs, why straight women might prefer gay dance clubs.

The straight dance clubs in close proximity to my primary data site were similar to the straight club I had recently visited with one of my gay participants. Standing outside were excessively tanned women with large breasts and mini-skirts and their tall, muscular boyfriends with spiked hair and impassive facial expressions; each of them exuding hegemonic gender norms. At the gay dance clubs, heterosexual women could dance with gay men who were not going to exploit them or render them little more than sex objects. Heterosexual women did not have to perform the femininity game at gay dance clubs (see LeBlanc, 1999.)

The problem with heterosexual women's use of gay dance clubs, however, is that it further pushes out lesbian women from a space that is already male dominated. While heterosexual women escape the objectifying male gaze at gay dance clubs, lesbian women wonder if there is a place left where they can feel comfortable and accepted. Lisa stated, "There are lots of straight women. I feel uncomfortable because I don't want to hit on one and have them get upset. You just don't know here because it's such a mixed crowd." Lesbians who are looking for a partner or someone to "hook up" with are finding it increasingly difficult to do in a space where it once was possible. One of my bisexual female friends had a similar problem at another gay club. She explained, "I was at [name of other club] hitting on this girl only to find out she was there with her boyfriend. I was like, 'what the fuck are you doing at a gay club?"'

Lesbian subculturalists are experiencing the negative effects of subcultural diffusion (see Image D). Heterosexual women are discovering gay clubs as trendy places to drink and dance with gay men. During this process, the original values and meanings behind gay club culture are defused, especially for lesbian women who are not able to claim a space and feel accepted. Heterosexual men are not using the space as frequently as are heterosexual women; thus, most gay men are still able to participate in the subculture without feeling ostracized or outnumbered by their heterosexual counterparts. I asked my gay male participants about straight men at the clubs and one responded: “There is always one straight guy, but it doesn't bother me. They think they're gonna get hit on, but we'll probably just make fun of what he's wearing." When I asked about straight women, he stated, "It doesn't bother me [having straight women at the club]. I do get a little weirded out when I see a straight couple kissing. I'm like 'really?' You could do that anywhere!" This helps show some of the negative effects cultural diffusion can have on gay men when heterosexual couples enter the scene. Not surprisingly, gay men are not bothered much by heterosexual women at the clubs and many enjoy having them as dance partners. 


\section{ANALYSIS}

One of the ethical concerns I had while conducting this research was misrepresentation. I spent most of my time participating in the subculture, without revealing myself as a researcher. One of my lesbian participants may have thought that I was interested in "hooking up" with her, as we spent over an hour conversing at a secondary data site. The way I dealt with these misrepresentations is that I tried to refrain from building long-term relationships with my participants. I focused on gathering the data I needed without leading anyone to believe I was interested in anything more than friendship.

My two gay male contacts are friends who knew I was conducting research, although they did not know the specifics. However, knowing my researcher status may have led them to behave differently or answer questions based on what they thought I wanted to hear. Participants in my study may have acted differently because I am a female. Gay men that I talked to may have felt less comfortable answering some of my questions about females specifically. They may have refrained from saying anything unfavorable about females, thinking that I would respond negatively. To reduce these concerns, I tried to remain neutral throughout the research. I refrained from outwardly disagreeing with any of my participants' statements or giving my personal opinion.

Going into research such as this, there is always the issue of confidentiality. Some individuals who participate in the gay dance club subculture do not want public others to know their sexual orientation. Being "outed" can cause some gay men and lesbians to lose their families or jobs, for example. In order to respect participants' privacy, I made sure to protect the identity of the individuals so no one could be traced back to my study. I used pseudonyms for my participants and for the primary and secondary date sites in my journals, field notes, and research paper (Blazak 2012).

During this research, I did not witness any illegal behavior, nor did I have to participate in any illegal behavior. I did, however, engage in drinking and on one occasion, I smoked a cigarette in order to initiate conversation with a lesbian woman who was smoking. Participating in these activities helped me "fit in" with the subculture and obtain data. Due to the fact that most individuals were drinking at the club, I would have looked like an outsider if I had not consumed alcohol, as well.
Similar to the gay dance club Tigerheat, where Peterson (2011) conducted his research, I found that the gay dance club where I conducted my research played predominantly female pop music artists. Gay men performed dance choreographies to heteronormative lyrics, therefore reversing the meaning of the song and reclaiming it for their own sexual expression (Peterson 2011, 621). Gay men's dance choreographies also became more feminized, with fluid dance styles, rhythmic movement of the hips, and engagement with a partner (Peterson 2011). Unlike most of the gay men in Connell's (1992) study, I found that gay men in the dance club subculture resist hegemonic masculinity in more ways than simply being gay. Connell (1992) states that homosexuality is the negation of hegemonic masculinity. I argue that gay men in the dance club subculture resist hegemonic masculinity through feminized forms of dance to female pop artists, while overtly expressing their sexuality with other gay men. They do this, however, in a space that is male dominated and sectioned off from mainstream society.

Throughout my research, I observed the ways in which gay men perform gender differently than do heterosexual men in the dominant culture. Not only are gay men in the dance club culture style innovators, they also exhibit Hebdige's concept of bricolage. Gay male dance clubbers express feminine forms of body language, actively engage in conversation with other gay men, and exchange flirtatious glances with each other. Gender performance is much more fluid and involves sensual and playful touching on and off the dance floor. Dance styles often include acting out sexual fantasies and sexual seduction (Peterson 2011, 622). Gay men in this subculture wear well-fitted, revealing clothing to display their bodies sexually for other men. Styles of clothing become more feminized with low-cut V-neck $\mathrm{t}$-shirts to show off pec-cleavage, for example.

Similar to Holt and Griffin's (2003) study and Casey's (2004) study, the gay dance club subculture I observed was predominantly white and middle-class. Although there were Hispanic and black participants, these ethnicities were underrepresented in the gay dance club subculture. This may reflect a general trend of gay dance clubs in Western culture, as Holt and Griffin conducted their study in Birmingham, UK and Casey conducted his study in London, UK and both presented similar demographics (Holt and Griffin 2003; Casey 2004). 
I also found that gay dance clubs are important places for gay men. They utilize gay dance clubs as a way to be themselves and embrace their sexual identities. The more homophobic a dominant culture, the greater the need for gay clubs to provide an escape from heteronormative associations within public space (Peterson 2011; Holt and Griffin 2003). Similar to Holt and Griffin's (2003) findings, I also noted instances in which style in the gay club culture was used either to "police" gay identities or distinguish homosexual identity from heterosexual identity. Lisa, one of the lesbian participants in my study distinguished herself from straight 'femme' women based on differing styles and reacted negatively toward them. This was similar to how lesbians in Holt and Griffin's study reacted toward 'femme' women (Holt and Griffin 2003, 411-413). Gay male participants in my study also distinguished themselves from straight men based on clothing, defining what was fashionable or outdated.

As more heterosexual females frequent gay clubs, lesbian women are further pushed out of the scene. Results from Casey's (2004) study and Holt and Griffin's (2003) study indicate that gay men dominate the gay dance club scene, and the increasing number of heterosexual women leaves lesbians with little space in the subculture. My study at Flames yielded similar findings. Gay men outnumbered lesbian women in the club, on the dance floor, and even as employees at the club. Guided conversations with lesbian women uncovered negative feelings toward heterosexual diffusion in my study and in the studies conducted by Casey (2004) and Holt and Griffin (2003). My grounded theory is that gay men in the dance club subculture resist hegemonic masculinity norms of the dominant culture by engaging in feminine forms of dance to pop music produced by female vocalists, and by openly expressing their sexuality with other gay men. This resistance occurs within the confines of male dominated space and may or may not continue outside of the clubs. Gay dance clubs are important places in which gay men and lesbians can escape the heteronormative dominant culture. However, with the diffusion of heterosexual women into the subculture, lesbian women are further pushed out of an already male dominated space, leaving them with little space to claim as their own. 


\section{LIMITATIONS}

I was able to achieve internal validity by painting an accurate picture of the gay dance club subculture. Utilizing participant observer and complete observer roles on some occasions limited the scope and depth of my research; whereas performing my role as a known researcher, enabled me to collect more detailed information. Using the known researcher role, however, is not without limitations. Participants may have altered their behavior or answered questions based on what they thought I wanted to hear. Being female and studying male participants may have also affected my internal validity. Male participants may feel more comfortable with a male researcher and thus more likely to reveal thoughts that they presume would offend a female. Due to time constraints, I was only in the field for six nights (approximately 18 hours). I was also limited to conducting research on Friday and Saturday evenings, which may have yielded different results than research carried out on weekdays.

The problems with external validity, or generalizability, in conducting this research were that I had a small sample size, used a non-probability sampling method, and my research was conducted in a unique geographic location. Small sample sizes are often not generalizable to the subculture as a whole. Convenience sampling is subject to researcher bias, as the participants I chose were not based on a random sample. There are also some differences between the Northwest city where I conducted research and other cities, which may render the study non-generalizable to the larger population. The progressive city where I conducted research is more accepting of gay and lesbian individuals than other cities in the United States. It is also a predominantly white and middle class city, which is reflected in the demographics I observed.

This study could be expanded to specifically focus on lesbian participation in the gay dance club subculture and whether they also resist hegemonic gender norms. The study should also seek to understand whether gay men continue to resist hegemonic masculinity norms outside of the dance clubs. Subsequent studies could also focus more on black or Hispanic gay dance club subculturalists, as these populations have been underrepresented in many studies. It would be interesting to find out whether other gay clubs in the United States are experiencing heterosexual diffusion, especially those in the South, where heterosexual and homosexual spaces tend to be more segregated than in the city where I conducted my research.
Appendix A: Glossary

Bricolage: A concept originated by Dick Hebdige, referring to style innovators taking raw materials from the environment and repositioning them to give things a new value (Blazak 2012)

Diffusion: Spreading of the subculture into mainstream culture (Williams 2011, 84) leads to defusion of the original values and meaning (Blazak 2012)

LGBTQ: Lesbian, Gay, Bisexual, Transgender, and Queer

Pec-cleavage: The space between a man's pectoral muscles, often accentuated by gay men in the dance club culture by wearing low-cut, V-neck t-shirts.

"Pink Triangle District": An area in some large cities that can be claimed as "gay space," usually featuring a number of gay bars, clubs, and shops (Oregon Encyclopedia 2008). 


\section{BIBLIOGRAPHY}

Babbie, Earl. 2005. The Basics of Social Research, Canada: Wadsworth.

Blazak, Randy. 2012. “Sociology of Youth Subcultures.” Class Lecture Notes, Spring 2012.

Casey, Mark. 2004. “De-Dyking Queer Space(s): Heterosexual Female Visibility in Gay and Lesbian Spaces." Sexualities. Vol. 7. pp.446-461

Connell, R.W. 1992. “A Very Straight Gay: Masculinity, Homosexual Experience, and the Dynamics of Gender." American Sociological Review. Vol. 57 No.6, pp.735-751.

"Gay and Lesbian Rights Movement." Oregon Encyclopedia: Oregon Culture and History. Portland State University, 2008-2012. Web. 15 May 2012.

Holt, Martin and Christine Griffin. 2003. “Being Gay, Being Straight and Being Yourself: Local and Global Reflections on Identity, Authenticity and the Lesbian and Gay Scene." European Journal of Cultural Studies. Vol. 6, pp. 404-425.

LeBlanc, Lauraine. 1999. Pretty in Punk: Girls' Gender Resistance in a Boys' Subculture, United States: Rutgers University Press.

Lofland, John and Lyn H. Lofland. 1995. Analyzing Social Settings, United States: Wadsworth.

Peterson, Grant Tyler. 2011. “Clubbing Masculinities: Gender Shifts in Gay Men's Dance Floor Choreographies." Journal of Homosexuality. Vol. 58, pp.608-625.

Tunnell, Kenneth D. 1998. “Honesty, Secrecy, and Deception in the Sociology of Crime: Confessions and Reflections from the Backstage," in Ethnography at the Edge: Crime, Deviance, and Field Research, (Jeff Ferrell and Mark Hamm, eds.), Boston: Northern University Press, pp.206-220.

Williams, J. Patrick. 2011. Subcultural Theory, UK: Polity Press.

This work is licensed under a Creative Commons AttributionNonCommercialNoDerivs 3.0 Unported License. 